\title{
Racism and Representation of Racialized Beauty in Toni Morrison's The Bluest Eye
}

\author{
Dr. Nirjharini Tripathy \\ Assistant Professor \\ School of English \\ Gangadhar Meher University \\ Sambalpur, India \\ neerjatrip2018@gmail.com
}

\begin{abstract}
The American novelist Toni Morrison's novel The Bluest Eye portrays black society and deals with the themes of black victimization and racial oppression. It presents a prolonged representation of the means in which the standards of internalized white beauty contort the life and existence of black women. This paper explores and elucidates the impact of race, racial oppression and representation in The Bluest Eye. And how racism also edifices the hatredness between Blackand White communities. This paper will discuss various issues and concepts such as Race, Race in the Colonial Period, Racializing the Other and Stereotyping. The paper also deals with understanding Representation through the ideas of Saussure, Barthes, Levi-Strauss, Foucault, Geertz, and Said. Racism is primarily a belief in the supremacy and dominance of one race upon another that consequences in the differences, discrimination and prejudice of people towards one another rooted and established on their race or ethnicity. Racism has deeply affected the African-American coloured people making them feel inferior. The Bluest Eye reflects the appalling effect on blacks individualising the values of a white culture that rejects them both immediately and incidentally. Even after
\end{abstract}


abolition of slavery legally still the African-Americans faces the cruelty of racial discrimination and never considered equal to the whites. The Black people struggles to ascertain themselves with the white and their ethnic ways. Toni Morrison propounds on black cultural heritage and seeks the African-Americans to be gratified and proud of their black colour as well black identity. This paper conveys the essence of the coloured people's fight for their race, and also its continuance and forbearance in a principally multicultural White dominated America.

Keywords: Beauty, Black, Race, Racism, Representation, White.

\section{Introduction}

Race can be defined as the scabrous cleaving of humans on the basis of anatomy, used as a modern term in the milieu of nation or ethnic group. It is also explicated as an identifiable group of people sharing a common descent, qualities associated to birth, where people nurture in a specific and distinct society and achieve social norms of the society, such as the Indo-Aryan, the Mongoloid, the Dravidian, etc. Research also says that there has been impact of climateon physical features, nature and behaviour.

There are different vital moments when the west experienced the black people and portrayed them through various discourses. The connection and dealings between the European traders and the West African realm which dispensed the black slaves for three centuries permitted rising of the black slavery. Another major reason could be the European colonization of African countries. The most important cause is the migrations of the people post-world war II from the third world countries into Europe and North America.

Various other things that plays role in this field are the concepts like exclusion, fantasy, power, otherness and stereotyping. Stereotyping evolves from the word typing which 
is any mere, basic, evocative, indelible, easily clenched and extensively identified characterization in which certain attributes are prominent and alter or progress is retained minimal. It brings down people to little, basic, vital characteristics that can be represented as firm by nature. It sets and firms difference, installs strategy of division and differences. It erects boundaries.

Edward Said states how Europe established a stereotypical statuette of the Orient. Foucault through his power/ knowledgediscourse providesvariousexecution of representation. It connotes useof language to speak or indicate something significant about or project the world in a worthwhile manner to other people. Representation is an inherent aspect of the procedure through which meaning is yielded and interchanged between components or adherents of a culture. It incorporates the utilization of signs and images that upends for or represent things. Edward Said through representing the Other defines Representation as the process by which representatives of a culture employs language to provide meaning when they represent the Other.

Ferdinand De' Saussure opines that the output of meaning leans on language. Language is order and arrangement of images, paintings, pictures, symbols, sounds, etc. maybe with words or without words. It assists to convey ideas which is a part of the structure of conventions. Nature and natural entities serves as signs. All cultural entities communicates meaning, thus all cultural practices hang on meaning, which is contrived and compliant to interpretation.

Clause Levi-Strauss researched the customs, practices, traditions, rituals, symbolic objects, motifs, myths, patterns, folktales and popular culture of the Brazilian people to discover what exactly they were communicating. He examined their meaning and significance by focussing on the fundamental and cardinal rules, regulations, ethics and systems by which these objects conveys meaning. He simply did not interpret the content. 
Foucault interpreted and conveyed a different and new approach of representation. According to him, Representation is related with creation of knowledge and not just meaning. He says that, discourses such as the customs, practices, traditions, rituals, symbolic objects, motifs, myths, patterns, folktales and popular culture produces knowledge and not just meaning. He associates knowledge with power.

Culture carries its own perception on the notion of beauty. Beauty is measured and its measurement is certainly not committed as it rests on how a person sees, contemplates and presume. The standards of beauty keep changing as per the environment and society. In AfroAmerican heritage and society, racialised beauty has inimical limpact in the lives and relationships of the people. The Bluest Eye deals with this discrimination in stipulations of beauty and race, the core themes in the novel. The young girl protagonist in the novel is too young, and as she grows up, she realises her ugliness and blackness, which is the extreme despicable fact of race relations.

Morrison, one of the prominent literary figures in contemporary Afro-American literature, received the Nobel Prize for her exceptional benefaction to English literature. Morrison questions the western standard of beauty and put forward the concept of beauty which is a societal creation and forming. She divulges that if whiteness is employed as a standard of beauty, then the worth of blackness is shrinked and declined. The Bluest Eye is the tale of an eleven year old black girl, Pecola Breedlove, who aspires to have a pair of blue eyes, as she presumes and feels that blue eyes, which the white people have, symbolises beauty. Thus the novel assesses the tragic impact of thrusting white American archetype of beauty on the maturing and expanding female identity of Pecola. Morrison indicates how such manufactured social standard of beauty shapes the little black girl's opinion, thereby making her feel inferior, weak and repulsive. Thus, the novel specifically ushers the plight and predicament of a black girl in the typical white American society mostly in 1930's and 
1940's, which was actually the evident and extreme period of racial tensions. The prevalent norm and notion at that time was that black and white are unequal in all aspects and can never be equal at any point of life and living.

The novel begins with the presentation of an absolute perfect white family where Dick and Jane live with their loving parents in a pleasant and enjoyable house. This example of an ideal white family performs as the dominant power of an ideology, the supremacy of the blue eyes through which the dominant white society recreates its hierarchy of power and order. It forces and pushes the victim to acknowledge that they are born inferior and should learn to oppress their own black identity by incorporating the worth that set down standards of beauty. Morrison presents this racial hierarchy by writing: "Here is the house. It is green and white. It has a red door. It is very pretty. Here is the family. Mother, Father, Dick, and Jane live in the green-and-white house. They are very happy.”(Morrison 2).

Morrison presents this Dick and Jane example to juxtapose the hardship life of the black children. It represents the apparently perfect, wealthy, happy, white family, which invades upon the lives of the black families. It juxtaposes the family of Pecola, where her mother and father always fight, condemns their own daughter Pecola and hates her because of her ugliness, that shoves her to wish for a pair of blue eyes. It drives her to the explication of the kinds of families in the world. She discovers to understand the concept of white beauty and is forced to believe that she is ugly and her misery is her ugliness and being black. She starts fantasizing that if she would have been born white then she would have never been raped by her own father, would not been hated by her mother, would not have been isolated by her own community and would rather have been admired and adored by her family and society.

Pecola Breedlove is an instance and model of the injured and inimical image who is inadequately encircled by the standard of beauty, a norm and yardstick is being elevated in a 
community where black are contemplated as menial and inferior. Shirley Temple, her peer, has the blue eyes, the standard of beauty represented by the white. It intensely expresses the psychological depredation of a young black girl, who hunts for love, affection and acceptance in a society that rejects and depreciates people of her own race. She is shirked, exploited and abhorred. She thinks that she is disliked by everyone around her both inside and outside her community because of being black and ugly. She thinks that the only solution for this problem and remedy for her ugliness is a pair of blue eyes. She wished for a pair of blue eyes that the white girls have. Thus, she is put through racism both inside and outside her race, that means by the black community as well as the white community.

Pecola's conviction that she can be loved, admired and accepted by people around only by changing her appearance is quite evident of racial self-revulsion and abhorrence. She feels lonely, isolated, secluded and stray. Thus she realizes that a pair of blue eyes can treat her equally with the whites. This evidently justifies that her foremost anxiety and botheration is to break free from delinquency from inside her home. She will be respected by her own community also. Morrison writes:

If she looked different, beautiful, maybe Cholly would be different, and Mrs. Breedlove too. Maybe they'd say', 'Why, look at pretty- eyed Pecola. We mustn't do bad things in front of those pretty eyes.(Morrison 44)

It had occurred to Pecola some time ago that if her eyes, those eyes that held the pictures, and knew the sight if those eyes of hers were different, that is to say, beautiful, she herself would be different, as say that those eyes are all Pecola will ever want in her lifetime, once in a blue moon, she just yearns for an acknowledgement.(Morrison 46)

Pecola appears to be the vital centre of the entire community's hatredness. Pecola's ugliness assists all to feel beautiful. Her frailness made all feel powerful. Her degradation to the 
'Other' made everybody else the superior. She becomes the personification of failure racially. Morrison justifies this point by describing the incident where Pecola goes to buy a candy from a shop owned by a white American man:

Somewhere between retina and object, vision and view, his eyes drawback, hesitate, and hover. At some fixed point in time and space he senses the need not to waste the effort of a glance. He does not see her, because for him there is nothing to see (Morrison 48).

Pecola's self-respect dearths any kind of worth or affirmation in the consideration of the 'Other' since her existence was absolutely unacknowledged. She was compressed into selfresistance, an emptiness denoting nothing, a complete lack of acceptance as a human being. Pecola realizes that her failure of self is aligned to her blackness. Morrison writes: "All things in her are in flux and anticipation. But her blackness is static and dread. And it is the blackness that accounts for, that creates, the vacuum edged with distaste in white eyes". (Morrison 49).

The sensibility of ugliness propels her to a tenacious childhood speculation that she might someday wake up and find herself blond and blue-eyed. So, understanding the psychology of a young black girl, it clearly indicates that black people are fighting against the forced standards by white-dominated society, and are struggling to fix their own ideal and prototype of self-esteem, accomplishment and security. Just to accentuate how firmly Pecola strives to achieve the social standard of white beauty Morrison writes:

Each pale yellow wrapper has a picture on it. A picture of little Mary Jane, for whom the candy is named, smiling white face. Blond hair in gentle disarray, blue eyes looking at her out of a world of clean comfort.... To eat the candy is somehow to eat the eyes, eat Mary Jane. Love Mary Jane. Be Mary Jane. (Morrison 50). 
Furthermore, Morrison discusses the vicious ways that a young black girl follows in order to attain the idealized image of white beauty. Morrison expresses the mental turmoil of Pecola and writes:

she picks Mary Jane's candy, not because of its taste, but because of its packaging bearing a picture of blonde, blue-eyed, beautiful Mary Jane. Above all, Pecola believes that she is one step closer to Mary Jane by consuming whiteness." (Morrison 90)

The traumatic impact and realisation of racialised beauty aggravates at Mrs. Breedlove's workplace that initiates Pecola's journey as a distressed child to psychosis. While Pecola accidentally strikes against a blueberry cobbler, rather than comforting Pecola, Mrs. Breedlove reproves her, hits her and eases the Fisher girl. This incident proves her mother's predilection for the white people. Also Pauline didn't want to admit in front of the whites that Pecola is her own daughter. Morrison writes:

Pick up that wash and get out of here, so I can get this mess cleaned up..... Mrs. Breedlove rushed and calms the white girl. "Who were they Polly?" Hush don't worry none,' she whispered, and the honey in her words complemented the sundown spilling on the lake."(Morrison 107)

An already disturbed, disappointed and rejected young girl Pecola accepts the fact that she is unwelcome, undesirable and unpleasant. The fact that ultimately drives Pecola to insanity is getting raped by her own father and carrying her father's child in her womb at the age of thirteen. This sad story of an exploited young girl is Morrison's opposition, dissent and protest against racism.

Pecola was betrayed by her own mother. She mentioned about the hateful rape but Mrs. Breedlove did not believe her. We got to know this when Pecola talks to her imaginary friend being insane: 
I wonder what it would be like. Horrible. Really? Yes. Horrible. Then why didn't you tell Mrs. Breedlove? I did tell her! I don't mean about the first time. I mean about the second time, when you were sleeping on the couch. I wasn't sleeping! I was reading! You don't have to shout. You don't understand anything, do you? She didn’t even believe me when I told her. So that's why you didn't tell her about the second time? She wouldn't have believed me either. You're right. No use telling her when she wouldn't believe you.(Morrison 198)

Pecola getting raped and pregnant at the age of thirteen by her own father exposes the brutality, savagery, barbarism and inhumanity of people around Pecola inside her own family, own black community and white community. Morrison represents this bestiality in her writing: "We had dropped our seeds in our own little plot of black dirt just as Pecola's father had dropped his seeds in his own plot of black dirt." (Morrison 10).Pecola didn't get any support, assistance, comfort or geniality from anyone. She was compelled to leave school because of her pregnancy and is secluded from other children. She lives a solitary life. She is left to suffer the anguish, pain and shame all by herself. Morrison describes: "They were disgusted, amused, shocked, outraged, or even excited by the story. But we listened to the one who would say, "Poor little girl," We looked for eyes creased with concern, but saw only veils." (Morrison, 190).

Pecola then is identified as 'the other' discrimination inside her own community that denounces her to an intense and ultimate ugliness. Pecola is an example of the impediment of being black. The child inside the womb of Pecola dies. At the last stage of her life and insanity, she abominates herself as she couldn't meet the standard of beauty set by the racialised society and thus fails to get accepted by the white society. Deprived of this white societal acceptance, Pecola frames her own world in her insanity and breaks free to the sphere where she finds herself beautiful. Her imagination creates her own community, detaching her 
from brutality that she experiences in her real life, and thus triumphs in shielding herself from pain, suffering and heartbreak. At last, the insane mind of Pecola attains a pair of blue eyes, in her imagination.

\section{Conclusion}

Morrison indicates that the protagonist Claudia is a protest and challenge to the white beauty establishment. Through Claudia, Morrison defies the discernment of the concept of beauty of the Whites which generally believes that beauty represents only the blue-eyed, blonde-haired, and white-skinned. The authority, master and domination of the society were the Whites that restraints Claudia to confront the power of the white dictators around her. Morrison by defying the Western standards of beauty opines that the standard of beauty is a societal construction. Morrison also exhibits that if whiteness is the yardstick of the standard of beauty, then the worth of blackness is depreciated. It is necessary for the entire human race to completely understand that culture holds, impacts and forms our worth and conviction. Thus, taking into consideration the value of culture, people can aspire to struggle and prosper to their highest prospective. Through the character of Claudia, Morrison describes how the internalized racism can damage the people of a community. Morrison shoots up from the conventional heritage of African-American society, culture and literature and thus represents racism as an explicit evil. 


\section{References}

Bloom H. Toni Morrison's The Bluest Eye (Bloom's Modern Critical Interpretations. New York: Chelsea House Publications, 2007. Print.

Doughlass, Frederick. Narrative of the Life of Frederick Doughlass. 1995. Print.

Geertz, Clifford. The Interpretation of Cultures. NY: Basic Books, 1973. Print.

Hall, Stuart. Representation: Cultural Representations and Signifying Practices. Delhi: Sage, 2007.

Matus, Jill. "Shame and Anger in The Bluest Eye". Manchester: Manchester University Press. 1998. Print.

Miner, M. M. Lady no longer sings the blues: Rape, madness, and silence in The Bluest Eye. Bloomington: Indiana UP. 1985. Print.

Morrison, Toni. The Bluest Eye. Great Britain: Vintage. 1999. Print.

Ogunyemi, Chikwenye. "Order and Disorder in Toni Morrison's The Bluest Eye", Critique: Studies in Modern Fiction, Vol. 19. 1977, 112-120. Print.

Rosenberg R. Seeds in hard ground: Black girlhood in The Bluest eye. Black American Literary Forum 21.4. 1987, 435-439. Print. 